\title{
Pea lectin inhibits cell growth by inducing apoptosis in SW480 and SW48 cell lines
}

Farhadul Islam ${ }^{1,2}$, Vinod Gopalan ${ }^{2}$, Alfred K-Y Lam ${ }^{2, *}$, Syed Rashel Kabir ${ }^{1, *}$

${ }^{1}$ Department of Biochemistry and Molecular Biology, University of Rajshahi, Rajshahi-6205, Bangladesh

${ }^{2}$ Cancer Molecular Pathology, School of Medicine and Griffith Health Institute, Griffith University

\section{Address for correspondence*}

Dr. Syed Rashel Kabir, Associate Professor, Department of Biochemistry \& Molecular Biology, University of Rajshahi, Rajshahi 6205,Bangladesh

e-mail: rashelkabir@gmail.com /rashelkabir@ru.ac.bd

Tel: 880-1558796153, 880-1

Professor Alfred K. Lam, Head of Pathology, Griffith Medical School, Gold Coast Campus, Gold Coast QLD 4222, Australia. E-mail: a.lam@griffith.edu.au

Telephone +61 7 56780718; Fax +61 756780303

Keywords: colon cancer; apoptosis; protein expression

Running title: Pea lectin inhibits SW480 \& SW48 cells growth.

Number of Figures: Six (6) 


\section{Abstract}

Globally, colorectal cancer is the third most common type of malignant tumor, after lung and breast. Here anticancer property of pea lectin was evaluated against colorectal cancer cell lines SW480 and SW48. The cells were treated with different doses of lectin for 3 days in vitro and the inhibitory effects were found in a dose dependent manner. At the high dose(1.0 $\mathrm{mg} / \mathrm{ml}$ ) $62 \%$ and $63 \%$ cell growth inhibitions were observed for SW48 and SW480 cell lines, respectively. Cell growth inhibition was further studied by colony formation of the cell lines and the numbers of colonies in $\mathrm{SW}_{480^{+p e a}}$ lectin and $\mathrm{SW} 48^{+ \text {pea lectin }}$ cells were noted significantly lower in comparison to that of control cells. Cell morphological study revealed that pea lectin induced apoptosis both in SW48 and SW480 cell lines, which was further confirmed by caspase inhibitors. Involvement of intrinsic mitochondrial pathway in the apoptosis progression was confirmed by caspase inhibitors and increased of caspase- $3 \&-9$ proteins expressions. Expression levels of p53 and p21 protein were also increased significantly in both cell lines with the decreased of PARP1 protein expression. $\mathrm{G}_{2} / \mathrm{M}$ and $\mathrm{G}_{0} / \mathrm{G}_{1}$ cell cycle arrested was noted in SW48 and SW480 cell lines, respectively, after treatment with pea lectin. 


\section{Introduction}

Lectins are a group of proteins or glycoproteins, other than antibodies and enzymes that specifically recognize cell surface molecules with at least two binding sites to carbohydrates resulting in cell agglutination. More recently, lectins are referred to as proteins possessing at least one non-catalytic domain that binds reversibly to a specific mono- or oligosaccharide $[1,2]$. Lectins are translators of the sugar code [3]. Lectins can be classified in various ways; one of the most common ways of classification is according to their structures and subunits [2]. Lectins are found in all kinds of organisms like plants, bacteria, viruses, fungi and animals. Plant lectins represent a unique group of proteins with potent biological activities, such as agglutination, toxicity, anti-proliferation of cancer cells as well as having anti-fungal and anti-bacterial activities [4-7]. Several plant lectins have been shown to have antitumor activity and induce apoptosis in a series of tumor cell lines [4,6,8-12].Over the last few decades, interest in lectins has been growing due to its wide variety of biological properties and applications, including clinical, biochemical, and agricultural aspects.

Pisum sativum L. belongs to the Leguminosae family sweet in test, round and dark green in colour. Pisum sativum well known as Pea, and is popular crop in Bangladesh, India China and Europe. Recently, lectins with different molecular weights were isolated from the Pea. They also differ in N-terminal sequences and biological activities [13]. It may be due to the differences in cultivars. Previously, Sitohy et al [7] reported strong agglutination activity of pea lectin against rat, human and rabbit erythrocytes, whereas weaker agglutination activity against chicken erythrocytes [7]. They also reported that Pea lectin inhibited the growth of Trichoderma viride, Fusarium oxysporum and Aspergillus flavus. Kojima and Jay [14] reported that Pisum sativum agglutinin have high affinity for Ehrlich ascites tumor. Recently, Pea lectin was isolated in our laboratory [4] and the molecular weight and sub units were same as reported by Sitohy et al. [7]. The lectin inhibited 11.7-84\% Ehrlich ascites 
carcinoma (EAC) cells proliferation at $8.0-120 \mu \mathrm{g} / \mathrm{ml}$ of protein concentration. The lectin also inhibited $63 \%$ tumor growth at $2.8 \mathrm{mg} / \mathrm{kg} /$ day dose [4]. It was also observed that haemoglobin and red blood cell (RBC) level increased significantly with the decreased of white blood cell (WBC) level towards the normal. The inhibitory effects due to the induction of apoptosis that was confirmed by the cell morphological study, caspase inhibitors and apoptosis related genes expression. The lectin caused the cell cycle arrest at $G_{2} / M$ phase of EAC cells [4]. Pea (Pisum sativum L.), lectin inhibited the EAC cell growth by inducing apoptosis. However, the anti-cancer activity of the isolated Pea lectin has never been tested against human cancer cells. Therefore, to test the anti-cancer effects of the isolated pea lectin against human cancer cells, colorectal cell lines SW480 and SW48 was used in the present study.

\section{Materials and Methods}

\section{Chemicals and reagents}

Unless otherwise stated, all the reagents and chemicals used in this study are of analytical grade and purchased from Sigma-Aldrich (St. Louis, Missouri, USA). Sepharose4B and diethylaminoethyl (DEAE) cellulose were purchased from Sigma (USA) and Wako (Chuo-ku, Tokyo, Japan) respectively. Anti-mouse monoclonal PARP1, and $\beta$-actin antibodies were procured from Santa Cruz biotechnology (Dallas, Texas, USA). Anti-rabbit monoclonal p53, p21, caspase-9 and casepase-3 antibodies were purchased from Abcam (Melbourne, VIC, Australia). Reagents and washing solutions used in the experiments were prepared with phosphate buffer saline (PBS, $10 \mathrm{mM}, \mathrm{pH}$ 7.4). Antibodies, proteins and cell extracts were diluted in phosphate buffered saline (PBS). Pisum sativum (Pea) seeds were collected from the local market. 


\section{Purification and characterization of Pea lectin}

Lectin was purified from Pisum sativum seeds followed by the protocol previously published by Kabir et al. [4]. Briefly, Pea seeds were homogenised, centrifuged and supernatant was freeze dried. The freeze dried powder was dissolved in Tris-HCl buffer (pH7.8), dialyzed and centrifuged at 10,000 rpm for 10 minutes. Then the supernatant was applied on DEAE cellulose column followed by glucose-sepharose column. The bound lectin was eluted by TBS containing $20 \mathrm{mM}$ ethylenediaminetetraacetic acid (EDTA) or $1 \mathrm{M}$ urea. The eluted fraction was dialyzed against $10 \mathrm{mM}$ Tris- $\mathrm{HCl}$ buffer containing $1 \mathrm{mM}$ of $\mathrm{CaCl}_{2}$. Finally, the homogeneity of the purified lectin was analysed by SDS-PAGE in $15 \%$ polyacrylamide gel. Hemagglutination activity was performed as described by Kabir et al [4].

\section{Cell culture}

SW480 and SW48 colon cancer cell lines line were used in this study. The cell lines were maintained according to American Type Culture Collection (ATCC) guidelines. Cancer cell lines SW-480 and SW-48 were maintained in Leibovitz's L-15 medium containing 10\% fetal bovine serum (FBS) and $1 \%$ penicillin/streptomycin at $37^{\circ} \mathrm{C}$ in a $\mathrm{CO}_{2}$ incubator.

\section{Cell proliferation assay}

A cell proliferation assay using a cell counting kit-8 (Sigma-Aldrich, Sydney, NSW, Australia) was performed to observe the effects of Pea lectin on proliferation of colon cancer cells. Both SW-480 and SW-48 cells were first seeded in flat-bottom 96-well plates at $1 \times$ $10^{4}$ cells/well. Cells were treated with Pea lectin at different doses $(0.25,0.5$ and $1.0 \mathrm{mg} / \mathrm{mL})$ after 24 hours of initial seeding (day 0 ). Then the proliferation rate was determined on days 1 to 3 after the treatment using CCK-8 (cell counting kit-8) following the previously published protocol [15]. CCK-8 assay utilize highly water soluble tetrazolium salt WST-8 [2- 2-(2- 
methoxy-4-nitrophenyl)-3-(4-nitrophenyl)-5-(2,4-disulfophenyl)-2H-

tetrazolium,monosodium salt] to produces water-soluble formazan dye upon reduction in the presence of an electron carrier. The production of formazan (yellow colored) in each well by dehydrogenases is directly proportional to the live cells.

\section{Colony formation assay}

To determine the effect of Pea lectin treatment on clonogenic/cytotoxic capacity, equal numbers of cells $(\sim 1500)$ were seeded in 6-well plates with complete medium. After 24 hours of initial seeding, cells were then treated with Pea lectin at the dose of $1 \mathrm{mg} / \mathrm{ml}$. The cells were kept in the incubator at $37^{\circ} \mathrm{C}$ in $5 \% \mathrm{CO}_{2}$ and saturation humidity to grow and form the colonies. After two weeks, when microscopic clones were noted in the plate, growing of the cells was stopped. Then, the media was discarded and cells were washed with phosphate buffered saline (PBS). Afterwards, cells were fixed with $70 \%$ cold ethanol for 15 minutes at room temperature. Subsequently, the clones were stained with crystal violet $(0.5 \%)$ for 2 hours at room temperature and washed with tap water. Finally, after being airdried, images of the plates were taken and the clone formation rates and surviving fractions were calculated using the following formula-

Clone formation rate or plating efficiency $(\mathrm{PE})=\frac{\text { No. of colony formation }}{\text { No. of cells seeded }} \times 100$

Surviving fractions $=\frac{\text { No. of colony formation }}{\text { No. of cells seeded }} \times \mathrm{PE}$

\section{Apoptosis assay}

After 24 hours of incubation, apoptosis assays on Pea lectin treated and control $(1 \times$ $10^{6}$ ) cells were performed using an annexin V-FITC apoptosis detection kit (Invitrogen, 
Carlsbad, CA, USA). The numbers of annexin $\mathrm{V}$ and propidium-iodide positive cells were detected using BDFACS Calibur (BD Biosciences, Franklin Lakes, NJ, USA) and data were processed with FlowJo v10 software (FlowJo LLC, Ashland, OR, USA).

Pea lectin induced apoptotic changes following treatment in the colon cancer $(\sim 10,000)$ cells also were assayed by using nuclear stain, Hoechest 33342 . In short, cells were fixed in $4 \%$ paraformaldehyde for 10 minutes and permeabilised with $0.1 \%$ Triton-X100 for 5 minutes at room temperature. After washing with PBS, the cells were stained with Hoechest $33342(10 \mu \mathrm{g} / \mathrm{ml})$ for 30 minutes at $37^{\circ} \mathrm{C}$. Finally, the cells were observed under fluorescence microscope (Olympus) and percentages of apoptotic cells recorded in three independent experiments from different plates.

\section{Effect of caspase-3, -8 and -9 inhibitors on Pea lectin-induced cytotoxicity in cancer cells}

Cancer $(\sim 10,000)$ cells were treated with caspase-3 (z-DEVD-fmk, $2 \mu \mathrm{mol} / \mathrm{mL}$ ) caspase-8 (z-IETN-fmk, $2 \mu \mathrm{mol} / \mathrm{mL}$ ) and caspase-9 inhibitor (z-LEHD-fmk, $2 \mu \mathrm{mol} / \mathrm{mL}$ ) and incubated for 2 hours at $37^{\circ} \mathrm{C}$. The cells were then treated with Pea lectin $1.0 \mathrm{mg} / \mathrm{mL}$ and incubated for another 24 hours at $37^{\circ} \mathrm{C}$. Finally, the cytotoxicity was determined using CCK8 assay kits [16].

\section{Cell cycle analysis}

To analyse the cell cycle distribution upon Pea lectin treatment, treated and control/non-treated wild type $\left(1 \times 10^{6}\right)$ cells were fixed with cold $70 \%$ ethanol for one hour as previously described [17]. After washing with cold PBS, $5 \mu$ l of RNase A (10mg/ml) was added to the cells and incubated for one hour at $37{ }^{\circ} \mathrm{C}$. Finally, $10 \mu \mathrm{l}$ of propidium iodide solution $(1 \mathrm{mg} / \mathrm{ml})$ was added to the cell suspension and analysis was performed with flow cytometry (BD FACS Calibur, BD Biosciences). 


\section{Western blot analysis}

To investigate the expression of proteins specific to cell growth and apoptosis $(e . g$. PARP1, p53, p21, caspase-3, caspase-9) upon PL-1 treatment were studied by western blot analysis. Total proteins were extracted from Pea lectin treated and control cells with lysis buffer (Bio-Rad, Gladesville, NSW, Australia) followed the manufacturer's guidelines and subsequently were quantitated by absorbance spectrometry [17]. Afterwards, total protein (30 $\mu \mathrm{g}$ ) was separated by $15 \%$ SDS-PAGE (Bio-Rad) and transferred to nitrocellulose membranes (Bio-Rad). The membrane was blocked with $5 \%$ non-fat milk powder for 2 hours at room temperature. Then the membrane was incubated with anti-mouse monoclonal PARP1 and $\beta$-actin antibodies (Santa Cruz) at 1:500 and anti-rabbit monoclonal p53, p21, caspase-9 and casepase-3 antibodies from Abcam (Melbourne, VIC, Australia) (1:1000) overnight at $4{ }^{\circ} \mathrm{C}$. Membranes were then washed three times with PBS-T and incubated with mouse and rabbit secondary antibodies, respectively (Santa Cruz) (1:5000) at room temperature for 2 hours. Protein bands were developed and detected with a chemiluminscence HRP detection kit (Bio-Rad, USA). Images were taken with the ChemiDoc MP Imaging system (Bio-rad).

\section{Statistical analysis}

All the data were collected and entered into a computerdatabase,and the statistical analysis was executed using the Statistical Package for Social Sciences (SPSS) for Windows (version 24.0, IBM SPSS Inc., New York, NY, USA). Student's t-test and one-way analysis of variance (ANOVA) were performed for the analysis of continuous variables (e.g., data from in vitro assays) in categories. Results are shown as mean \pm SD (standard deviation) and the significance level was taken at $\mathrm{p}<0.05$. 


\section{Results}

\section{Purification of Pea lectin and Hemagglutination activity}

The lectin was purified using ion-exchange and affinity chromatography on DEAE cellulose and glucose-sepharose column, respectively. Approximately $20 \mathrm{mg}$ of Pea lectin was isolated from $200 \mathrm{~g}$ of Pea seeds. The purified lectin exhibited two separate bands $(\sim 5$ and $19.5 \mathrm{kDa}$ ) in SDS-PAGE gel corresponds to the alpha and $\beta$-subunit, respectively. The minimum hemagglutination activity for Pea lectin was noted to be $8 \mu \mathrm{g} / \mathrm{mL}$ of rat erythrocytes. D-glucose and D-mannose were identified the best inhibitors for Pea lectin induced hemagglutination activity.

\section{Pea lectin inhibited proliferation of colon cancer cells}

Cancer cells treated with Pea lectin $\left(\mathrm{SW} 480^{+ \text {pea lectin }}\right.$ and $\left.\mathrm{SW} 48^{+ \text {pea lectin }}\right)$ showed reduced cell proliferation when compared to non-transfected wild type control cells $\left(\mathrm{SW} 480^{\mathrm{control}}\right.$ and SW48 ${ }^{\mathrm{control}}$ ). Pea lectin treatment leads to inhibition of colon cancer cell growth in a dose dependent manner (Figure 1A-2B). In SW480 ${ }^{+ \text {pea lectin }}$ cells, 17,35 and $63 \%$ of cell growth inhibition was observed at different doses $(0.25,0.5$ and $1.0 \mathrm{mg} / \mathrm{mL})$ in comparison to that of SW480 ${ }^{\text {control }}$ cells (Figure 1C). Similarly, 18, 36 and $62 \%$ cell growth inhibition was noted in SW48 ${ }^{+ \text {pea lectin }}$ when compared to that of SW48 ${ }^{\text {control }}$ cells (Figure 1D). It was noted that Pea lectin mediated inhibition colon cancer cells proliferation was persistent up to three days of the treatment (Figure 1).

\section{Pea lectin inhibited colony formation of colon cancer cells}

Pea lectinhadshown significant inhibition of the colony formation capacity of colon cancer cells $(\mathrm{p}<0.001)$. It was observed that $\mathrm{SW} 480^{+ \text {pea lectin }}$ and $\mathrm{SW} 48^{+ \text {pea lectin }}$ cells showed remarkably reduced colony formation properties in comparison to the 
SW $480^{\text {control }} \&$ SW $48^{\text {control }}$ cells (Figure $2 \mathrm{~A}$ ). The numbers of colonies in SW480 ${ }^{\text {+pea lectin }}$ and SW48 ${ }^{\text {+pea lectin }}$ cells were noted significantly lower in comparison to that of control cells (Figure 2B). Treatment $(1.0 \mathrm{mg} / \mathrm{ml})$ of the cancer cells with Pea lectin reduced the surviving fractions of cancer cells remarkably. Approximately, $14.3 \%$ and $9.6 \%$ surviving fractions were noted in SW480 $0^{+ \text {pea lectin }}$ and SW48 ${ }^{+ \text {pea lectin }}$ cells, respectively. On the contrary, 93.7\% and $90.4 \%$ surviving fractions were observed in $\mathrm{SW} 480^{\text {control }} \& \mathrm{SW} 48^{\text {control }}$ cells, respectively (Figure 2C).

\section{Pea lectin induced apoptosis of colon cancer cells}

The Annexin-V staining revealed a significant increase in apoptotic cells populations in SW480 $0^{+ \text {pea lectin }}$ and SW $48^{+ \text {pea lectin }}$ colon cancer cells when compared to the control cells (Figure 3A). Approximately $20.3 \%$ versus $2.4 \%$ and $24.8 \%$ versus $1.3 \%$ apoptotic cells were noted in SW480 and Sw48, respectively following of PL-1 treatment (Figure 3B). Furthermore, Hoechest 33342 fluorescence staining of SW480 and SW48 cells treated with Pea lectin showed significant nuclear morphological alterations indicative of cell apoptosis compared to control cells (Figure 3C-3D). Notably increased number of cells treated with Pea lectin showed apoptotic nuclei phenotypes when visualized under fluorescence microscope whereas control cells did not display any fragmented nuclei (Figure 3C-3D).

\section{Caspase-3 and -9 inhibitors pre-treated cells insensitive to Pea lectin induced cytotoxicity}

Caspase-3, -8 and -9 inhibitors were used to check the specific pathways involved in the induction of apoptosis in Pea lectin treated cancer cells. Pea lectin treatment showed 62$63 \%$ growth inhibitions at $1.0 \mathrm{mg} / \mathrm{ml}$ when compared to that of control cells (Figure 4A-4B). These cytotoxic activities of Pea lectin against cancer cells was decreased remarkably down 
to $16-23 \%$ in the presence of caspase-3 and -9 inhibitors (Figure 4A-4B). On the other hand, cancer cells pre-treated with caspase- 8 inhibitor was noted sensitive to Pea lectin treatment and had shown $\sim 45 \%$ cells growth inhibition (Figure $4 \mathrm{~A}-4 \mathrm{~B}$ ).

\section{Pea lectin treatment alters cell cycle kinetics in colon cancer cells}

Analysis of cell cycle kinetics revealed that cancer cells showed $G_{0} / G_{1}$ arrest and accumulation of cells in $\mathrm{G}_{2} / \mathrm{M}$ phases followed by Pea lectin treatment (Figure $5 \mathrm{~A}-5 \mathrm{~B}$ ). In

the case of SW $480^{\text {control }}$ cells, the percentage of $\mathrm{G}_{0} / \mathrm{G}_{1}$ phase cells was $25.2 \pm 3.5 \%$, while in $\mathrm{SW} 480^{+ \text {pea lectin }}$ cells, the $\mathrm{G}_{0} / \mathrm{G}_{1}$ phase population increased remarkably to $35.4 \pm 5.2 \% \%$ $(\mathrm{p}<0.05)$ (Figure 5B). On the other hand in $\mathrm{SW} 48^{+ \text {pea lectin }}$ cells, the percentage of $\mathrm{G} 2 / \mathrm{M}$ phase cells was increased significantly $(20.5 \pm 1.5$ versus $12.4 \pm 2.5)$ when compared to that of control cells (Figure 5C). These results indicated that Pea lectin inhibit colon cancer cells by arresting them at $\mathrm{G}_{0} / \mathrm{G}_{1}$ and $\mathrm{G}_{2} / \mathrm{M}$ phase of the cell cycle.

\section{Pea lectin modulated cell growth and apoptosis specific proteins expression}

Pea lectin treatment induced the activation of tumour inhibitors and repressed the expression of tumour promoting proteins in colon cancer cells. It was noted that Pea lectin deactivated the expression of tumour promoter PARP1 in both cell lines when compared to that of control cells (Figure 6). Pea lectin treated cells had shown increased expression of p53, and p21proteins in comparison to that of non-treated control cells (Figure 6). Also, it was observed that Pea lectin treated cells showed higher expression of caspase-3 and caspase9 in comparison to that of control cells (Figure 6). 


\section{Discussion}

Lectins are widely used for preparative and analytical purposes in biochemistry, cell biology, immunology, and related areas, particularly with glyco-conjugates. Plant lectin plays potential roles for the prevention and treatment of a wide range of diseases e.g. as a diagnostic and therapeutic tools for cancer. Legume lectins are one of the most extensively studied plant lectin families for their molecular basis of the protein-carbohydrate interactions. In recent years, the main interests in this lectin family due to their potential application as anti-tumour agents. Colon cancer is the third most common cancer in men and the second most common cancer in women worldwide. Although several lectins were used against different cancer cell lines but only few were reported against colorectal cancer cell lines [1821].

In our previous experiments, it was found that pea lectin shown anti-proliferative activities against Ehrlich ascites carcinoma cells, inhibited tumor growth with the significantly increasing of hemoglobin and $\mathrm{RBC}$ with the decreased of WBC levels toward the normal levelsin vivo in mice. The lectin caused $\mathrm{G}_{2} / \mathrm{M}$ cell cycle arrest and these effects were due to the apoptosis induction in EAC cells as confirmed by cell morphological study, caspase inhibitor and gene expression [4]. Mytogenic activity of pea lectin was also reported against mouse splenocytes [13]. Here, for the first time pea lectin was used to check the antiproliferative activity against SW480 and SW48 colorectal cancer cell lines. Effects of concanavalin A (Con A) and jacalin (AIL), SBA (soybean agglutinin), UEA (Ulex europaeus agglutinin from Ulex europaeus, WGA (wheat germ agglutinin) and tepary bean lectinon SW480 cell line were reported [21,22]. ConA, AIL and UEA helped the proliferation of SW480 while WGA and tepary bean lectin inhibited the proliferation at all concentrations $[21,22]$. It has been reported in literature that when malignant cells are exposed to different concentrations of lectin, the cells undergo severe damage and the cell viability and cell 
proliferation decrease remarkable [22-25]. These anti-cancer properties of lectin are dose and time dependent, had shown increasing activities with increased lectin concentration and increased exposure time to the cells [22-25].

In the present study, pea lectin inhibited SW48 and SW480 cell growth and the inhibitory effects increased with the increased concentration of lectin and the exposure times. The lectin effects on the cell lines were almost similar.Cell growth inhibition was also studied by colony formation of colon cancer cells. Pea lectin significantly inhibited colony formation of SW48 and SW480 cell lines andthe inhibitory effects were almost similar for the cell lines.

Each cell surface has carbohydrate make-up and when lectins come into contact with cells, they can bind with those carbohydrates or they can be internalized into the cells. This interaction of lectins with cells can trigger a wide variety of signals, including, induction of apoptosis or cell cycle arrest, suppression of telomerase activity, and inhibition of angiogenesis and ribosomal inactivation. In addition, it could activates the immune system by stimulating the proliferation of $\mathrm{T}$ lymphocytes, increasing the activity of tumor necrosis factor alpha (TNF)- $\alpha$ and inhibiting the release of anti-inflammatory interleukin (IL)-10 [2533]. Apoptosis is a program cell death and the effective chemotherapeutic agent causes apoptosis in cancer cells. During apoptosis some changes are observed in cancer cells, including, blebbing, cell shrinkage, nuclear fragmentation, chromatin condensation, chromosomal DNA fragmentation, and global mRNA decay. Different staining dyesare used to check the apoptosis induced morphological changes in cells. In the present study, cells were stained with Hoechst 33342 dye. This dye bound with DNA of SW48 and SW480 cells and some of the apoptotic features (blebbing, cell shrinkage, nuclear fragmentation, and chromatin condensation) were observed clearly. In addition, the induction of apoptosis was also studied by the Annexin-V staining that revealed a significant increase in apoptotic cells 
populations in SW480and SW48 cells lines after treatment with pea lectin when compared to the control cells.

It has been reported that most of the lectin causes apoptosis in mitochondrial and/or death receptor pathway [6]. Caspase-3 is the key protein, which is activated during apoptosis and cause DNA fragmentation as well as DNA damage. Caspase-3 can be activated in the apoptotic cell both by extrinsic (death ligand) and intrinsic (mitochondrial) pathway. In the extrinsic pathway, caspase- 8 activates caspase- 3 while in the intrinsic pathway caspase- 9 activates caspase-3 though activation of other proteins.Here in the presence of pea lectin and caspase $-3 \&-9$ inhibitors, SW48 \& SW480 cells proliferation were almost like control group, while no significant effects was observed in the presence of caspase- 8 . These results indicate induction of apoptosis occurred in the intrinsic pathwayboth in SW48 and SW480 cells. Western blotting analysis was used to check the expression level of caspase-3 \& -9 proteins after treatment with pea lectin. The expression levels were increased remarkably, which further confirmed the involvement of caspase- 3 and -9 in apoptosis process in the colon cancer cells. PARP1, poly(ADP-ribose) polymerase, is $113 \mathrm{KDa}$ nuclear protein that plays a key role in repairing single strand and double strand breaks of DNA [34]. Several papers demonstrated that PARP1 expression is significantly high in colon cancer and plays a role in colon cancer development $[35,36]$. In the present study expression level of PARP1 was decreased significantly both in the SW48 and SW480 cells lines after treated with pea lectin.

p53 plays is important for the cell cycle control and induction of apoptosis. It has been reported that due to mutant p53 gene, abnormal cell proliferation occurs which is in turns, causes cancer. In normal cells, p53 level is low but during DNA damage the expression of p53 may increased that may cause cell growth arrest that stop the progression of cell cycle and finally cause apoptosis. Here p53 level was increased for both cell lines after treatment 
with pea lectin. Although p53 is mutated but it may contain DNA binding capability, as a result p21 expression was increased significantly in both cell lines. p21 is a potent cyclindependent kinase inhibitor whose role is a regulator of cell cycle progression. The p21 protein binds directly to cyclin-dependent kinases and inhibits their kinase activity thereby causing cell cycle arrest [37]. In the present study percentage of $G_{0} / G_{1}$ phase was increased remarkable in SW480 while percent of $\mathrm{G}_{2} / \mathrm{M}$ cell population increased for SW48 cell line. These results indicate that Pea lectin inhibitsSW480 and SW48 cells growth by arresting them at different phases of the cell cycle.

In conclusion, Pea lectin inhibited SW48 and SW480 colorectal cancer cells growth and proliferation. Treatment of Pea lectin mediate alteration of cellular morphology, activates p53, p21, caspase-3 and -9 expressions and suppress PARP1 expression, thereby causes $\mathrm{G}_{2} / \mathrm{M}$ and $\mathrm{G}_{0} / \mathrm{G}_{1}$ cell cycle arrest and induce apoptosis of cells by activating mitochondrial intrinsic pathway. 


\section{References}

[1] W.J. Peumans, E.J. Van Damme, Lectins as plant defense proteins, Plant Physiol. 109 (1995) 347-352.

[2] E.J. Van Damme, W.J. Peumans, A. Pusztai, S. Bardocz, Handbook of plant lectins: properties and biomedical applications, 1998, England: Wiley.

[3] S. André, H. Kaltner, J.C. Manning, P.V. Murphy, H.J. Gabius, Lectins: getting familiar with translators of the sugar code, Molecules 20 (2015) 1788-1823.

[4] S.R. Kabir, M.M. Nabi, A. Haque, R.U. Zaman, Z.H. Mahmud, M.A. Reza, Pea lectin inhibits growth of Ehrlich ascites carcinoma cells byinducing apoptosis and $G_{2} / M$ cell cycle arrest in vivo in mice, Phytomedicine 20 (2013) 1288-96.

[5] S.R. Kabir, M.A. Hossen, M.A. Zubair, M.J. Alom, M.F. Islam, M.A. Hossain, Y. Kimura, A new lectin from the tuberous rhizome of Kaempferia rotunda: isolation, characterization, antibacterial and antiproliferative activities, Protein Pept. Lett. 18 (2011) 1140-1149.

[6] B. Liu, H.J. Bian, J.K. Bao, Plant lectins: potential antineoplastic drugs from bench to clinic, Mini-review, Cancer Lett. 287 (2010) 1-12.

[7] M. Sitohy, M. Doheim, H. Badr, Isolation and characterization of a lectin with antifungal activity from Egyptian Pisum sativum seeds, Food Chem 104 (2007) 971-979.

[8] S.R. Kabir, M.A. Reza, Antibacterial Activity of Kaempferia rotunda Rhizome Lectin and Its Induction of Apoptosis in Ehrlich Ascites Carcinoma Cells, Appl. Biochem. Biotechnol. 172 (2014) 2866-76.

[9] S.R. Kabir, M.M. Rahman, R. Amin, M.R. Karim, Z.H. Mahmud, M.T. Hossain, Solanum tuberosum lectin inhibits Ehrlich ascites carcinoma cells growth by inducing apoptosis and $\mathrm{G}_{2} / \mathrm{M}$ cell cycle arrest, Tumour Biol. 37 (2016) 8437-8444. 
[10] F.R.S. Ahmed, R. Amin, I. Hasan, A.K.M. Asaduzzaman, S.R. Kabir, Antitumor properties of a methyl- $\beta$-D-galactopyranoside specific lectin from Kaempferia rotunda against Ehrlich ascites carcinoma cells, Int. J. Biol. Macromol. 102 (2017) 952-959.

[11] M.S. Kim, H.S. So, K.M. Lee, J.S. Park, J.H. Lee, S.K. Moon, D.G. Ryu, S.Y. Chung, B.H. Jung, Y.K. Kim, G. Moon, R. Park, Activation of caspase cascades in Korean mistletoe (Viscum albumvar. coloratum) lectin-II-induced apoptosis of human myeloleukemic U937 cells, Gen. Pharmacol. 34 (2000) 349-355.

[12] E.G. De Mejía, M. Valadez-Vega, R. Reynoso-Camacho., G. Loarca-Pina, Tannins, trypsin inhibitors and lectin cytotoxicity in Tepary (Phaseolus acutifolius) and Common (Phaseolus vulgaris) Beans, Plant Foods Hum. Nutrit. 60 (2005) 137-145.

[13] T.B. Ng, Y.S. Chan, C.C. Ng, J.H. Wong, Purification and Characterization of a Lectin from Green Split Peas (Pisum sativum), Appl. Biochem. Biotechnol. 177 (2015) 137485.

[14] S. Kojima, M. Jay, Application of lectins to tumor imaging radiopharmaceuticals. Eur. J. Nucl. Med. 12 (1986) 385-389.

[15] F. Islam, V. Gopalan, S. Law, J.C. Tang, K.W. Chan, A.K. Lam,. MiR-498 in esophageal squamous cell carcinoma: clinicopathological impacts and functional interactions, Hum. Pathol. 62 (2017) 141-151.

[16] F. Islam, V. Gopalan, J. Vider, R. Wahab, F. Ebrahimi, C.T. Lu, K. Kasem, A.K.Y. Lam, MicroRNA-186-5p overexpression modulates colon cancer growth by repressing the expression of the FAM134B tumour inhibitor, Exp. Cell Res. 357 (2017) 260-270.

[17] F. Islam, V. Gopalan, R. Wahab, R.A. Smith, B. Qiao, A.K. Lam, Stage dependent expression and tumor suppressive function of FAM134B (JK1) in colon cancer, Mol. Carcinog. 56 (2017) 238-249. 
[18] B. Schnegelsberg, U. Schumacher, U. Valentiner, Lectin Histochemistry of Metastasizing and Non-metastasizing Breast and Colon Cancer Cells. Anticancer Res. 31 (2011) 1589-1598.

[19] C. Valadez-Vega, J.A. Morales-González, M.T. Sumaya-Martínez, L. Delgado-Olivares, A. Cruz-Castañeda, M. Bautista, M. Sánchez-Gutiérrez, C. Zuñiga-Pérez, Cytotoxic and Antiproliferative Effect of Tepary Bean Lectin on C33-A, MCF-7, SKNSH, and SW480 Cell Lines. Molecules 2014, 19, 9610-9627.

[20] T. Sato, M. Takahashi, T. Kawado, E. Takayama, K. Furukawa, Effect of staurosporine on N-glycosylation and cell adhesion to fibronectin of SW480 human colorectal adenocarcinoma cells, Eur. J. Pharm. Sci. 25 (2005) 221-227.

[21] G. Zárate, G.D. Sáez, A. Pérez Chaia, Dairy propionibacteria prevent the proliferative effect of plant lectins on SW480 cells and protect the metabolic activity of the intestinal microbiota in vitro, Anaerobe 44 (2017) 58-65.

[22] T. García-Gasca, M. García-Cruz, E. Hernandez-Rivera, J. López-Matínez, A.L. Castañeda-Cuevas, L. Yllescas-Gasca, A.J. Rodríguez-Méndez, E. Mendiola-Olaya, J.L. Castro-Guillén, A. Blanco-Labra, Effects of Tepary bean (Phaseolus acutifolius) protease inhibitor and semipure lectin fractions on cancer cells, Nutr. Cancer 64 (2012) 1269-1278.

[23] C. Valadez-Vega, G. Alvarez-Manilla, L. Riverón-Negrete, A. García-Carrancá, J.A. Morales-González, C. Zuñiga-Pérez, E. Madrigal-Santillán, J. Esquivel-Soto, C. EsquivelChirino, R. Villagómez-Ibarra, M. Bautista, A. Morales-González, Detection of cytotoxic activity of lectin on humancolon adenocarcinoma ( $\mathrm{Sw} 480)$ and epithelial cervical carcinoma (C33-A), Molecules 16 (2011) 2107-2118.

[24] C. Valadez-Vega, A.M. Guzmán-Partida, F.J. Soto-Cordova, G. Alvarez-Manilla, J.A. Morales-González, E. Madrigal-Santillán, J.R. Villagómez-Ibarra, C. Zúñiga-Pérez, J. Gutiérrez-Salinas, M.A. Becerril-Flores, Purification, biochemical characterization, and 
bioactive properties of a lectin purified from the seeds of white tepary bean (phaseolus acutifolius variety latifolius), Molecules 21 (2011) 2561-2582.

[25] E.G. De Mejía, V.I. Prisecaru, Lectins as bioactive plant proteins A potential in cancer treatment, Crit. Rev. Food Sci. Nutr. 45 (2005) 425-445.

[26] A. Castillo-Villanueva, F. Abdullaev, Plant lectins and their effects on cancer, Rev. Invest. Clin. 57 (2005) 55-64.

[27] S.Y. Lyu, S.H. Choi, W.B. Park, Korean mistletoe lectin-induced apoptosis in hepatocarcinoma cells is associated with inhibition of telomerase via mitochondrial controlled pathway independent of p53, Arch. Pharm. Res. 25 (2002) 93-101.

[28] F.I. Abdullaev, E.G. de Mejia, Antitumor effect of plant lectins. Nat. Toxins 5 (1997) 157-163.

[29] H. Bantel, I.H. Engels, W. Voelter, K. Schulze-Osthoff, S. Wesselborg, Mistletoes lectins activates caspase-8/FLICE independently of death receptor signaling and enhances anticancer drug-inducen apoptosis, Cancer Res. 59 (1999) 2083-2090.

[30] A. Büssing, G.M. Stein, U. Pfüller, M. Schietzel, Differential binding of toxic lectins from Viscum album L., ML I and ML III, to human lymphocytes, Anticancer Res. 19 (1999) 5095-5099.

[31] B. Liu, X.C. Xu, Y. Cheng, J. Huang, Y.H. Liu, Z. Liu, M.W. Min, H.J. Bian, J. Chen, J.K. Bao, Apoptosis-inducing effect and structural basis of Polygonatum cyrtonema lectin and chemical modification properties on its mannose-binding sites, BMB Rep. 41 (2008) $369-375$.

[32] F. Gong, Y. Ma, A. Ma, Q. Yu, J. Zhang, H. Nie, X. Chen, B. Shen, N. Li, D. Zhang, A lectin from Chinese mistletoe increases gammadelta $\mathrm{T}$ cell-mediated cytotoxicity through induction of caspase-dependent apoptosis, Acta Biochim. Biophys. Sin. 39 (2007) 445-452. 
[33] S. Joshi, D. Tomes, S. Pirruccello, H. Gabius, Galactoside specific VAA lectin-induced apoptosis in human leukemia cells, Proc. Am. Assn. Cancer Res. 35 (1994) 6.

[34] C. Beck, I. Robert, B. Reina-San-Martin, V. Schreiber, F. Dantzer, Poly(ADP-ribose) polymerases in double-strand break repair: focus on PARP1, PARP2 and PARP3, Exp. Cell Res. 329 (2014) 18-25.

[35] K. Hirai, K. Ueda, O. Hayaishi, Aberration of poly(adenosine diphosphate-ribose) metabolism in human colon adenomatous polyps and cancers, Cancer Res. 43 (1983) 34413446.

[36] K. Nosho, H. Yamamoto, M. Mikami, H. Taniguchi, T. Takahashi, Y. Adachi, A. Imamura, K. Imai, Y. Shinomura, Overexpression of poly(ADP-ribose) polymerase-1 (PARP-1) in the early stage of colorectal carcinogenesis, Eur. J. Cancer 42 (2006) 23742381.

[37] R.G. Baradwaj, M.V. Rao, T. Senthil Kumar, Novel purification of 1'S-1'Acetoxychavicol acetate from Alpinia galanga and its cytotoxic plus antiproliferative activity in colorectal adenocarcinoma cell line SW480, Biomed Pharmacother 91 (2017) 485-493. 


\section{Figure legends}

Fig.1. Effect of pea lectin on cell proliferation of SW480 and SW48 human colon cancer cells. Treatment of SW-480 (A) and SW-48 (B) cells with Pea lectin induce significant reduction of proliferation in comparison to control cells on different days of initial treatment. (B) \& (D) presented the percentages of growth inhibition of SW480 and SW48 cells, respectively, followed by Pea lectin treatment. Results are shown as mean $\pm \mathrm{SD}$. Level of significance $* \mathrm{p}<0.05, * * \mathrm{p}<0.01$ and $* * * \mathrm{p}<0.001$ when compared with that of control cells.

Fig.2. Effect of pea lectin on the colony formation of colon cancer cells. A) Treatment of Pea lectin $(1.0 \mathrm{mg} / \mathrm{mL})$ decreased the colony formation capacity of SW480 and SW48 cells. B) Bar graphs presented the number of colonies generated from lectin treated $(1.0 \mathrm{mg} / \mathrm{mL})$ and control cells. C) Surviving fraction of cells obtained from lectin treated and control cells. Results are shown as mean \pm SD. Level of significance $* * p<0.01$ and $* * * p<0.001$ when compared with that of control cells.

Fig.3. Induction of apoptosis in colon cancer cell lines. (A) annexin V and propidium-iodide positive cells after treatment with pea lectin $(1.0 \mathrm{mg} / \mathrm{mL})$ and control cells. (B) Percent of apoptotic cells increased after treatment with pea lectin. (C) \& (D) representing cell morphological changes of SW480 and SW48 cells after treatment with Pea lectin and staining with Hoechest 33342 fluorescence dye respectively.

Fig.4. Effects of Caspase-3, -8 and -9 inhibitors on the cytotoxic activities of pea lectin (1.0 $\mathrm{mg} / \mathrm{mL}$ ) on the SW480 (A) and SW48 (B) cell lines. 
Fig.5. Effects of Pea lectin on cell cycle distribution in SW480 and SW48 cells. The effects of pea lectin $(1.0 \mathrm{mg} / \mathrm{mL})$ on the cell cycle of SW480 and SW48 cellswere evaluated by flow cytometry.(A) Representing histogram of control SW480 and SW48 cells and after treatment with pealectin. The percentages of each cell cycle were analyzed based on mean values obtained from three independent experiments,(B) is representing SW480 and (C) is representing SW48 cell lines.

Fig.6. Expression of apoptotic related PARP1, p21, p53, caspase-3 and -9 proteinsexpression after treatment with pea lectin $(1.0 \mathrm{mg} / \mathrm{mL})$ and $\beta$-actin as internal control. 


\section{Highlight}

Pea lectin showed strong growth inhibition against SW48 \& SW480 cell lines.

The effect is due to the induction of apoptosis confirmed by caspase inhibitors.

Expression levels of p53 and p21 protein were increased significantly.

Expression levels of PARP1 protein decreased significantly.

$\mathrm{G}_{2} / \mathrm{M} \& \mathrm{G}_{0} / \mathrm{G}_{1}$ cell cycle arrested for $\mathrm{SW} 48$ \& SW480 cell lines, respectively. 
A)

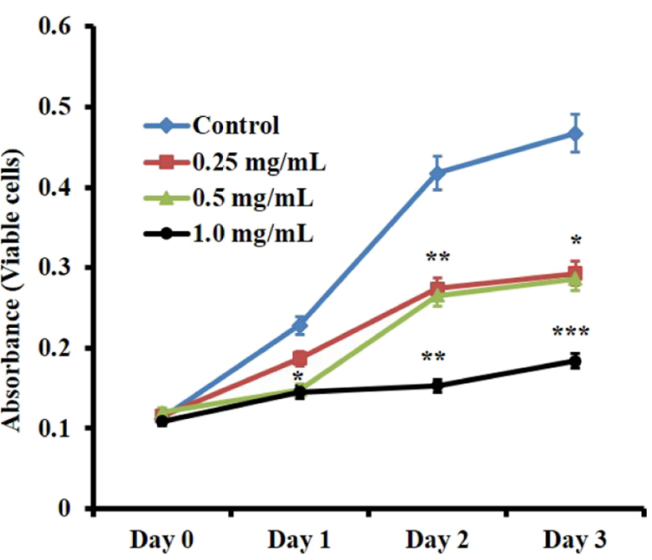

B)

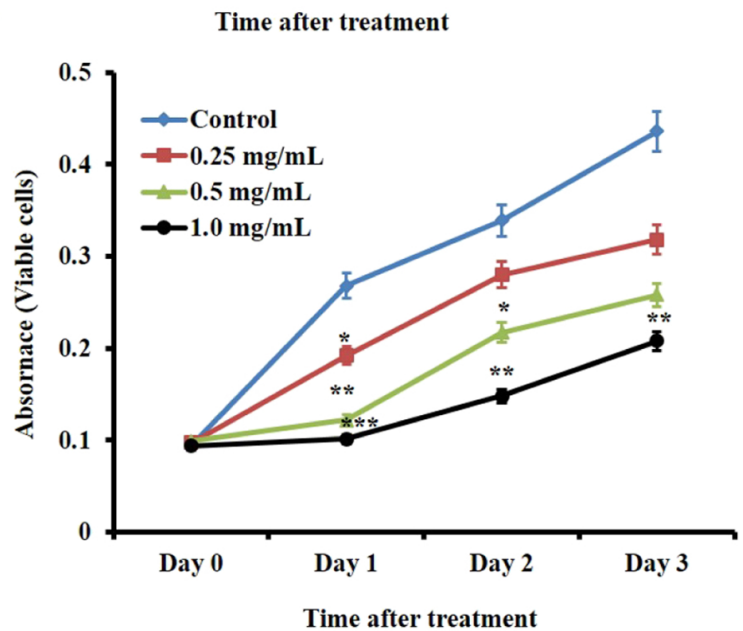

C)
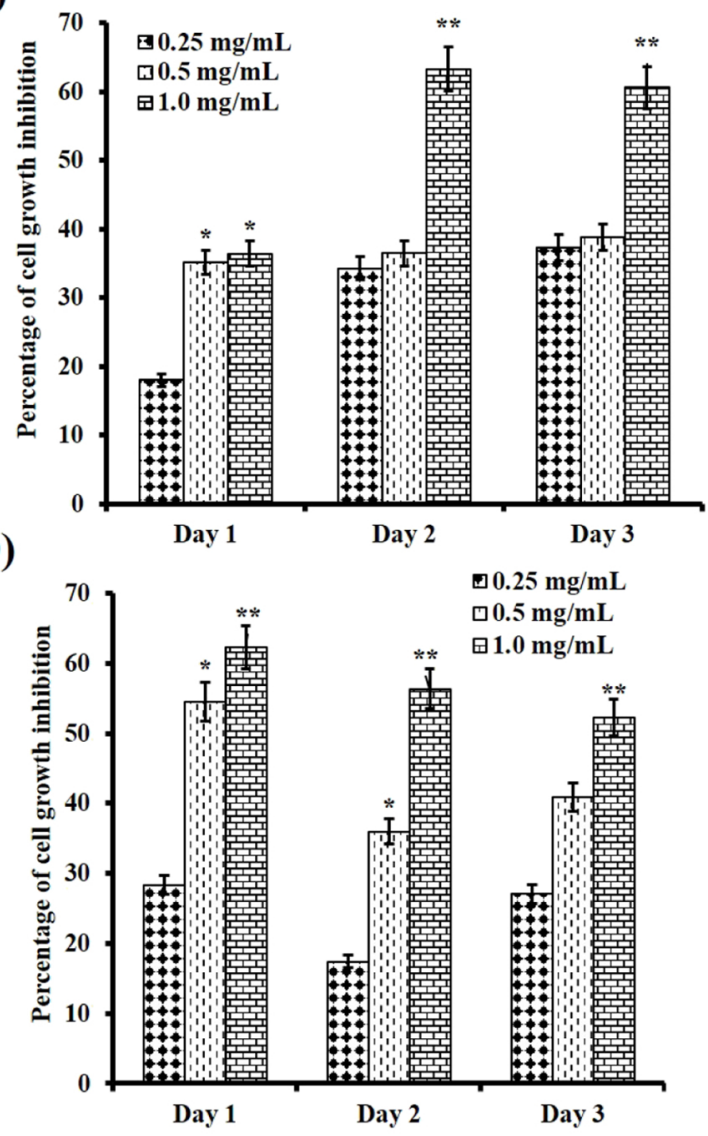

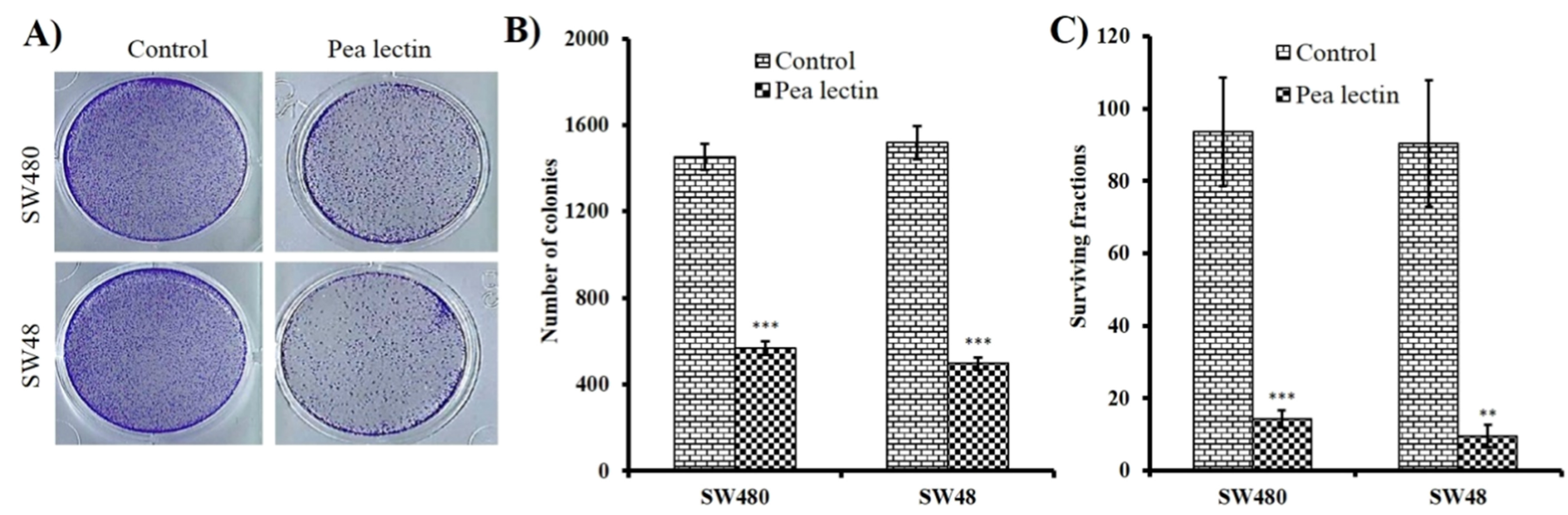

Figure 2 

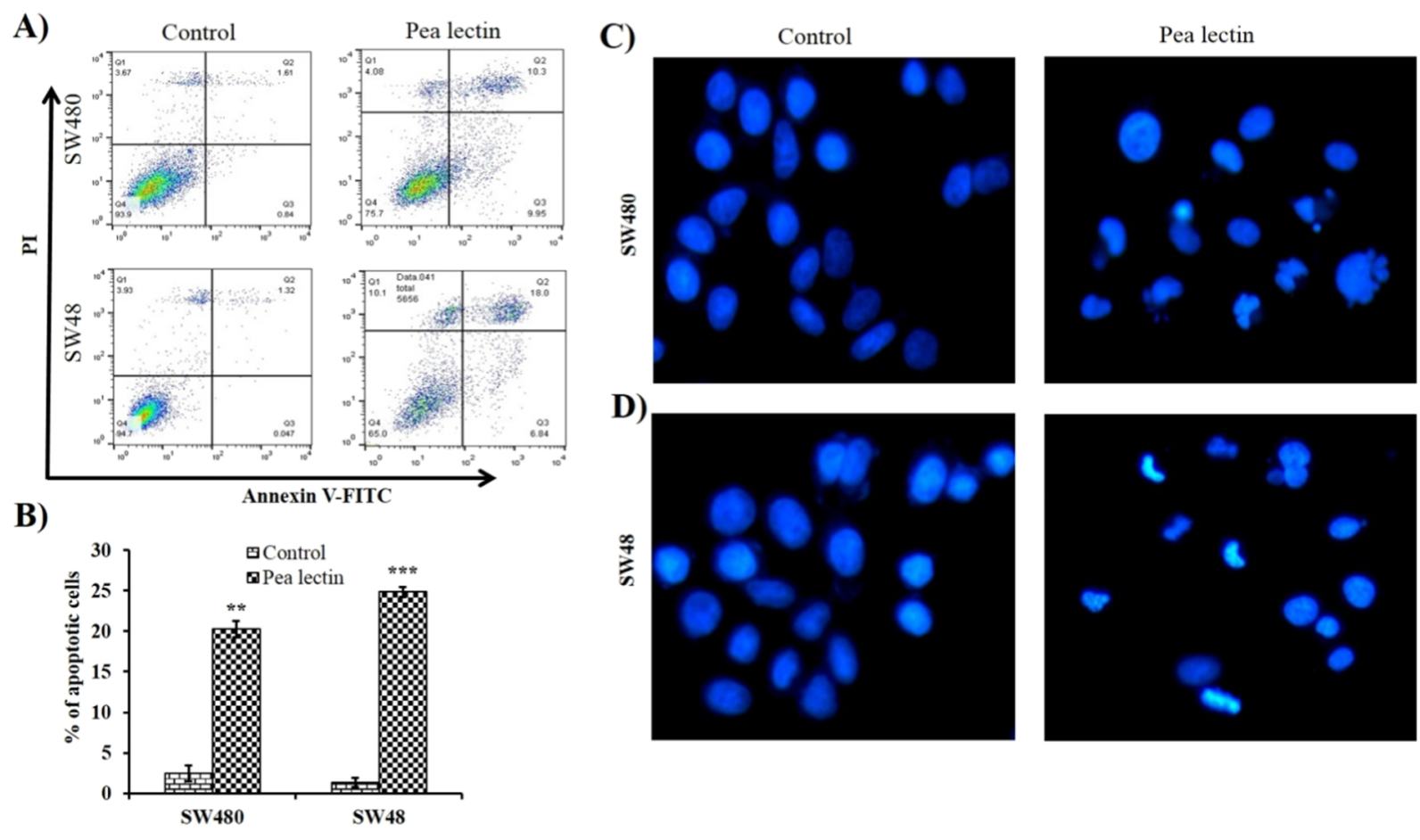

Figure 3 
A)

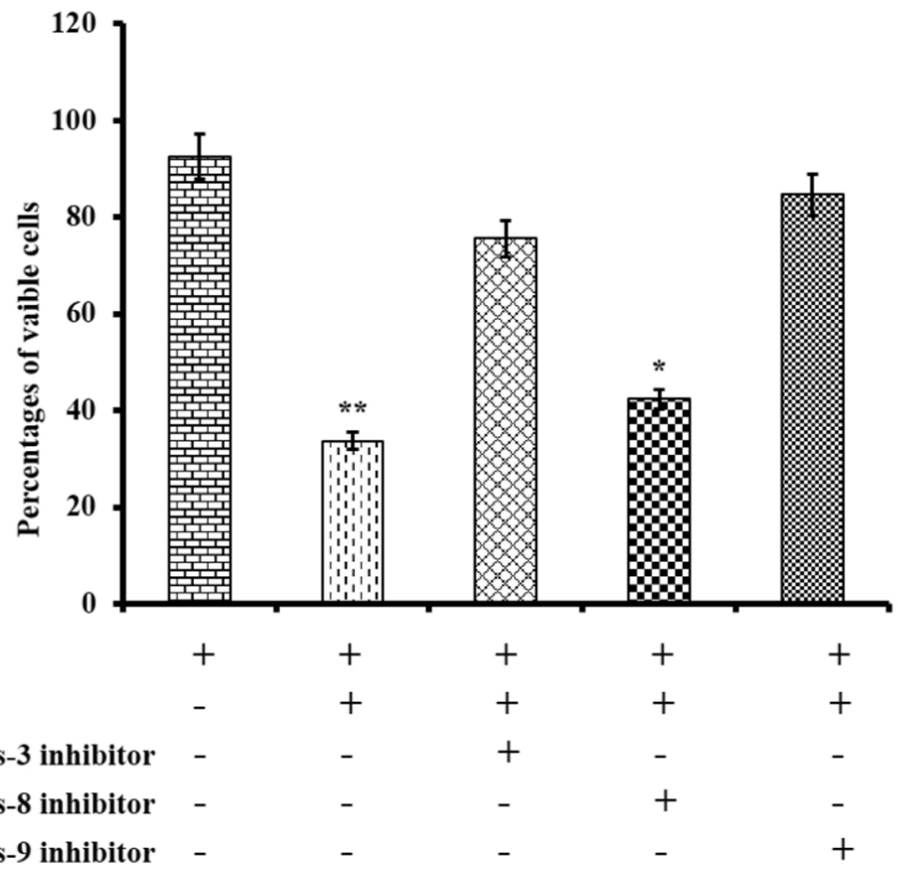

B)

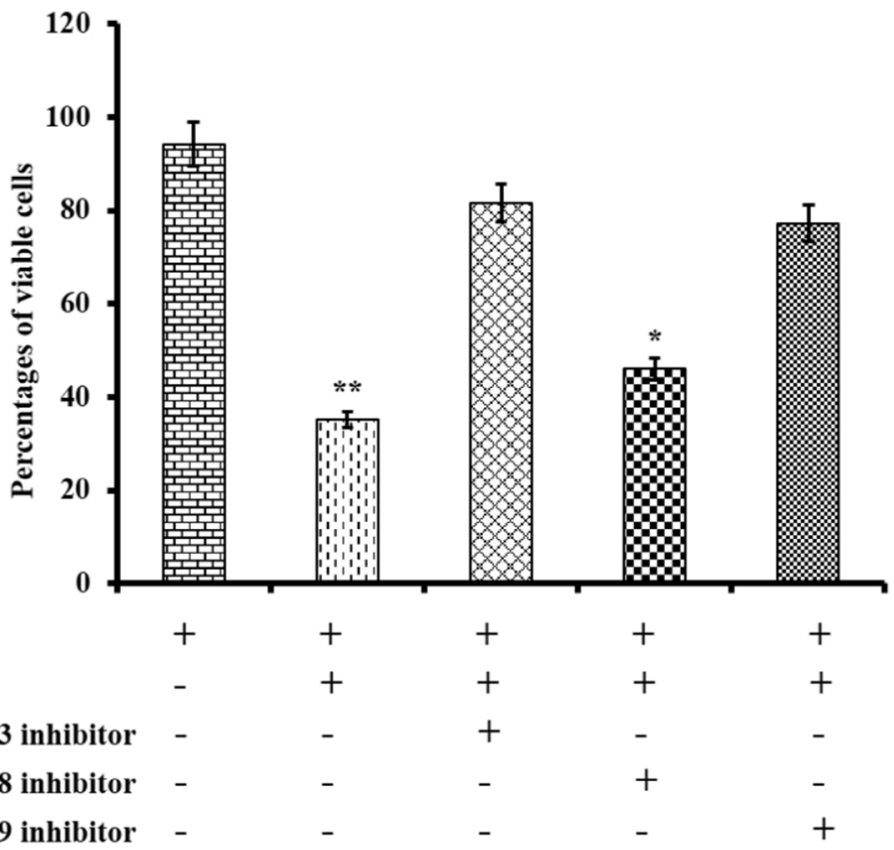


A)
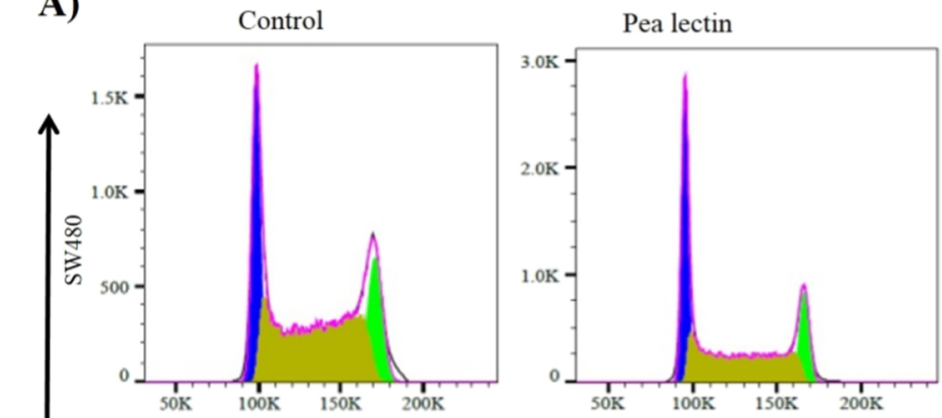

尝

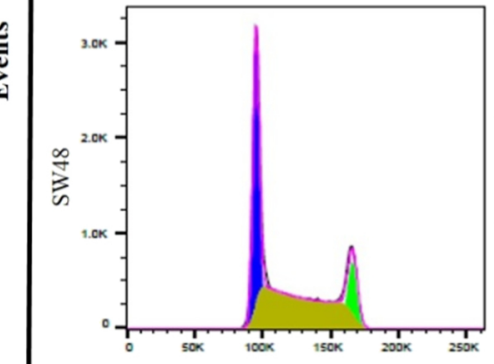

B)

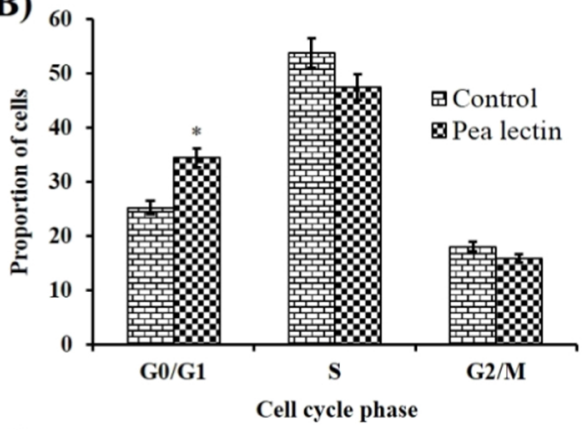

C)

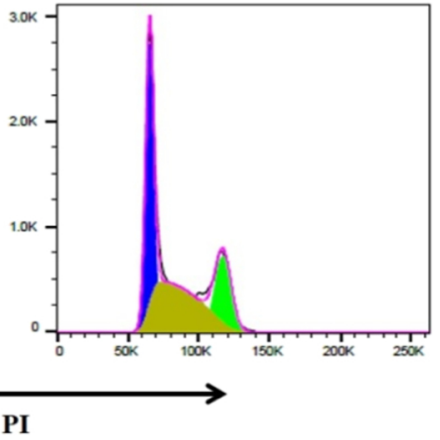

C)

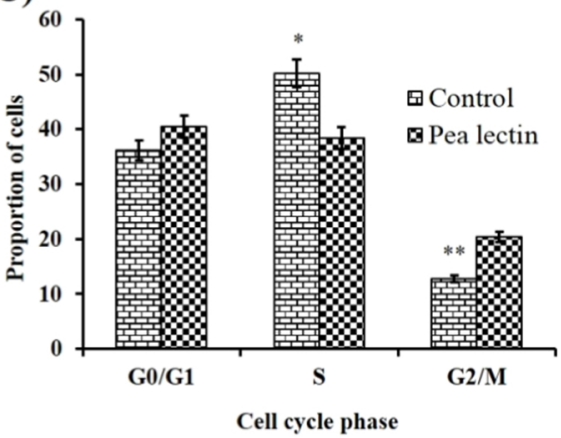

Figure 5 

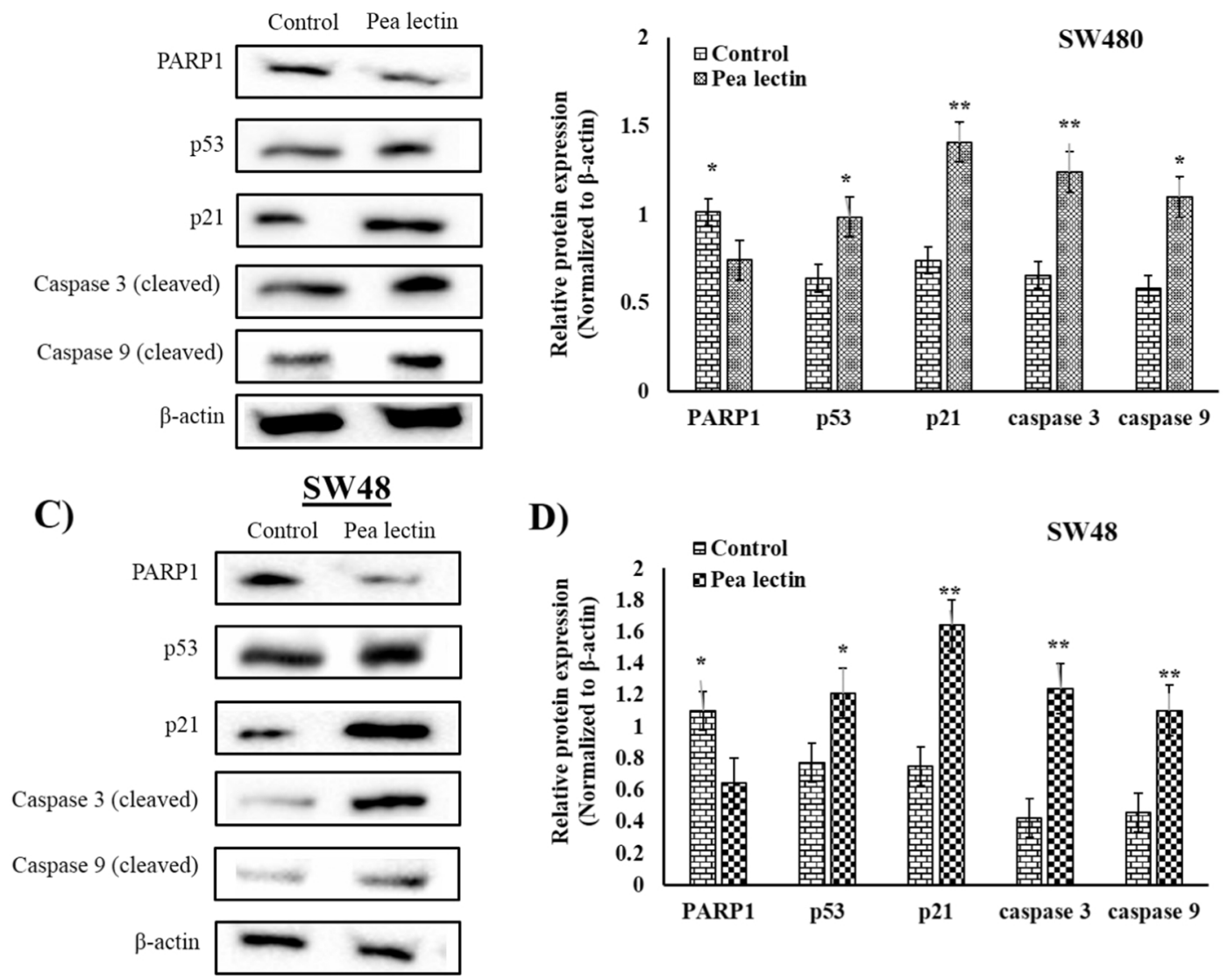

Figure 6 


\section{Accepted Manuscript}

Pea lectin inhibits cell growth by inducing apoptosis in SW480 and SW48 cell lines

Farhadul Islam, Vinod Gopalan, Alfred K.-Y. Lam, Syed Rashel Kabir

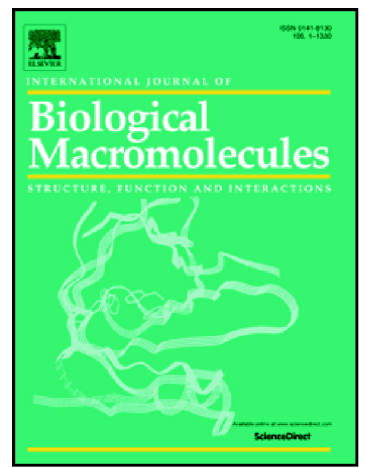

PII: $\quad$ S0141-8130(18)30187-9

DOI: $\quad$ doi:10.1016/j.ijbiomac.2018.06.021

Reference: $\quad$ BIOMAC 9861

To appear in: $\quad$ International Journal of Biological Macromolecules

Received date: $\quad 11$ January 2018

Accepted date: $\quad 5$ June 2018

Please cite this article as: Farhadul Islam, Vinod Gopalan, Alfred K.-Y. Lam, Syed Rashel Kabir , Pea lectin inhibits cell growth by inducing apoptosis in SW480 and SW48 cell lines. Biomac (2017), doi:10.1016/j.ijbiomac.2018.06.021

This is a PDF file of an unedited manuscript that has been accepted for publication. As a service to our customers we are providing this early version of the manuscript. The manuscript will undergo copyediting, typesetting, and review of the resulting proof before it is published in its final form. Please note that during the production process errors may be discovered which could affect the content, and all legal disclaimers that apply to the journal pertain. 